Boston University School of Law Scholarly Commons at Boston University School of Law

Faculty Scholarship

3-6-2012

\title{
American Influence on Israeli Law: Freedom of Expression
}

Pnina Lahav

Boston University School of Law

Follow this and additional works at: https://scholarship.law.bu.edu/faculty_scholarship

Part of the Comparative and Foreign Law Commons, Constitutional Law Commons, Jurisprudence Commons, and the Legal History Commons

\section{Recommended Citation}

Pnina Lahav, American Influence on Israeli Law: Freedom of Expression, Israel and the United States: Six Decades of US-Israeli Relations 187 (2012).

Available at: https://scholarship.law.bu.edu/faculty_scholarship/202 


\section{American Influence on Israeli Law}

\section{FREEDOM OF EXPRESSION}

\section{Pnina Lahav}

\section{Introduction}

From the inception of the Zionist movement, as the nineteenth century came to a close, Jewish families in Eastern Europe split. Some thought that only return to the Jewish homeland could resolve the plight of Jews in exile; others held that mass migration to Western countries, particularly the United States, would be the more realistic means to a good and meaningful life. ${ }^{1}$ This difference of opinion soon translated into a tension of cultures and values. For the first half of the twentieth century, even as the Zionist movement cultivated American Jews in an effort to encourage US support for a Jewish state, many of its leaders rejected any lessons they could draw from the American experience, let alone American law. In their minds, America stood for unfettered capitalism and rugged individualism, values diametrically opposed to their dedication to building a utopia in the holy land, based upon social justice and collective solidarity. As the discussion below reveals, Israelis have come to appreciate what America has to

\footnotetext{
I wish to thank Alon Harel, Moshe Negbi, and Zvi Triger for making valuable comments on this piece, and Carolyn Mattus, Yulia Shilovitsky, and Avi Robinson for research assistance. All errors are mine alone.
} 
offer in more than one way. American legal values and choices increasingly gained influence and prestige.

The legal system of Palestine inherited by the British Mandate in 1922, and left mostly in place when Israel declared independence in 1948, was shaped by Ottoman law and British colonialism. Therefore, it was quite untouched by American influences. ${ }^{2}$ Even today the basic Israeli legal structure and the content of its norms is largely rooted in either British colonial legislation (e.g., the penal code, the law of corporations, the law of evidence, tort law) or European influences, which is the heritage of the Europe-oriented Israeli legal elite (e.g., the law of contracts, the law of sales). In matters of constitutional design, the most glaring difference between the United States and Israel is the continuing Israeli resistance to a comprehensive written constitution. Ever since they achieved independence, Israelis have been discussing the need for a constitution. Each decade has seen its own set of proposals for a preferred version, but so far none has been adopted. Instead, Israel went to West Germany to borrow the term "basic law" while giving it a unique Israeli content. Rather than passing one comprehensive basic law, as the Germans have done, Israelis opted for a series of statutes they called basic laws, which were adopted over time. Thus, Basic Law: the Knesset, Basic Law: the Government, Basic Law: the Courts, and in the 1990s, Basic Law: Human Dignity and Freedom came into being. ${ }^{3}$ From the perspective of constitutional design, these basic laws reflect a system radically different from that of the United States.

To begin with, these laws are not firmly entrenched. ${ }^{4}$ The Knesset may amend most of their provisions with a simple majority. This makes them radically different from the US Constitution, where the amendment process is cumbersome and demanding. Additionally, there are several differences rooted in the form of governance. For example, in the US the president is elected for four years and, barring impeachment, is not dependent on the approval of Congress. In Israel, the principle of separation of powers is flexible, with the cabinet staying in power at the pleasure of the Knesset. Furthermore, the cabinet reflects a coalition: the variety of parties representing a majority of the 120 Knesset members. Fundamental disagreements between the coalition partners affect the range of policy choices open to the prime minister.

Similarly, there are several differences between the Israeli court system and the American judicial branch. The jury is not and has never been a part of the Israeli judicial system. Judges are appointed by a committee that includes members of the judiciary, the bar, the Knesset, and the cabinet. The Supreme Court of Israel operates as both an appellate high court and a "high court of justice." The latter is an institution introduced by the British Mandate but has since acquired a distinctly Israeli flavor. It allows ordinary citizens to challenge governmental action directly to the highest court without first going through the lower 
courts. Israelis are fond of this mechanism and make extensive use of it. ${ }^{5}$ The courts, as we shall see below, have come increasingly to consult American precedents as they contemplate the legal problems before them.

This brings us to Israeli legal education. As I have argued previously, legal education in Israel has seen a substantial transformation. In the 1950s it was largely based on European models with strong English overtones. Today an American student visiting one of the elite Israeli schools will find himself or herself quite at home. Israeli law professors are very familiar with American law and make extensive use of it. Their students, then, are not treading terra incognita as they visit an American legal institution or read American legal scholarship.

Similarly, Israeli law firms, particularly the big ones engaged in international business, have adopted the model of the American law firm and emulate its structure and patterns. ${ }^{6}$ Again, an American lawyer visiting one of these firms may find the environment quite familiar, and vice versa.

It appears, therefore, that one may confidently trace a historical pattern. Following its establishment, Israel's legal system bore very little resemblance to the American legal system. Over the decades, as Israel has forged a bond with the United States, partially due to political realignments and partially because of the universal process of globalization, American influence became more welcome and accepted. Today, just as one sees everywhere in Israel the fingerprints of American politics and culture, so may one detect the fingerprints of American law. A caveat, however, is in order: both American law and Israeli law are complex systems, coats of many colors. One should beware of overly broad generalizations. One should be mindful of the complexity and not assume too much coherence in the flow of influence from one side of the ocean to the other.

This essay addresses one area where the American influence on Israeli law has been quite evident: freedom of expression. The First Amendment to the US Constitution provides that "Congress shall make no law abridging the freedom of speech or of the press." This language invites speculation: what does "no law" mean? How should "abridge" be interpreted? How much should be included in the word "speech"? Throughout the nineteenth century, the First Amendment was not interpreted to protect much expression. ${ }^{7}$ After the First World War, however, the US Supreme Court developed a robust jurisprudence elaborating both a theoretical base and a set of doctrines designed to protect an expansive array of speech rights. This jurisprudence was also held to apply to the several states. ${ }^{8}$ In the twenty-first century no one doubts the significance of free speech as a core American constitutional value deserving and begetting zealous judicial protection. ${ }^{9}$

Five years after it was established, Israel's Supreme Court adopted this American legacy as its own. The transplantation was neither mechanical nor utterly successful. Still, it did take root and has been developed in ways that echoed 
developments in the United States. Today there is little doubt about the Israeli legal commitment to freedom of expression. I shall trace the American influence through representative cases in each of the six decades of Israel's life as a sovereign state. ${ }^{10}$

\section{The 1950s: Kol Ha'am v. Minister of the Interior}

Imagine a legal system where the press is regulated by a special statute that requires each newspaper to obtain a license prior to publication. Further, imagine that a public official (the minister of the interior, in Israel's case) is vested with the power to suspend the license and close down the newspaper if he determines that the newspaper was publishing materials that may cause a breach of the peace. In other words, the law gives the minister unbridled discretion. Imagine, too, that the polity has just emerged from a bloody war, is surrounded by enemies, and is facing a world skeptical of its right or strength to exist. Imagine that the state is anxious to find allies and supporters, but attracts none, that it yearns for unity and solidarity and feels that controversy and contentiousness are harmful. If such a legal system has no written constitution and a five-year-old hesitant and restrained Supreme Court, how would importing American jurisprudence of free speech be possible?

Simon Agranat, the Israeli Justice who authored the opinion in Kol Ha'am v. Minister of Interior, offered the answer. ${ }^{11}$ Agranat was born in Louisville, Kentucky, and grew up in Chicago, Illinois. He attended the University of Chicago both as an undergraduate (majoring in history) and as a law student. An avid Zionist, he immigrated to Palestine in 1929, shortly after obtaining his law degree. Agranat's fervent Zionism did not prevent him from deeply loving and appreciating what the United States had to offer. These qualities helped him when he came to write the opinion in this seminal case, which all agree has laid the solid foundations of Israeli administrative and constitutional law, moving Israel's legal system away from colonial authoritarianism and toward democratic liberalism.

The newspaper Kol Ha'am (The People's Voice) belonged to the Israeli Communist Party and promoted the party's platform. On January 14, 1953, it published an editorial alleging that Israel had offered to send 200,000 troops to support the American effort in the war against North Korea. The specific allegation was false, but it was true that Israel's government at that time was in the process of abandoning its "neutral" or "independent" position in matters of foreign affairs and beginning to support the United States. From the vantage point of the twenty-first century, these facts seem trivial. But one should be careful not to fall into the trap of ahistoricism. In the early 1950s, Israel had a robust 
left-wing political camp composed of several influential parties. The Cold War was raging and these parties tended to side with the Soviet Union. Israel's government and its left-leaning ruling party, Mapai, wished to maintain a neutral stance, both to secure the support of its left wing and out of concern for the large Jewish population behind the Iron Curtain. Thus, although Israel was beginning to seek American friendship and support, it was not yet willing to openly declare allegiance to American leadership. Into this complex web came the Kol Ha'am editorial, both criticizing vehemently and blowing out of proportion David Ben-Gurion's overtures toward the United States. Ben-Gurion was so vexed that he found it necessary and appropriate to deny the allegations from the podium of the Knesset. That step would be equivalent to the US president holding a press conference to deny certain news reports-a step indicating how seriously the need for denial was taken. In addition, the minister of the interior also decided to invoke the law and suspend the newspaper. When Kol Haim petitioned the Supreme Court, it was asking the Court to step into a rather hot political crisis. To aggravate matters for the Supreme Court, a three-month-old precedent, from the pen of the chief justice, held that the press ordinance gave the minister of the interior absolute discretion and that therefore there was no room for judicial intervention. ${ }^{12}$

In a unanimous opinion by a panel of three justices, Agranat ignored the precedent and invalidated the suspension order. The legal stepping stones he used were declaring that Israel was committed to the value of free expression, and elaborating on the theories that justify the need for this freedom in a democracy. The principle of free expression, he said, is particularly robust in the area of censorship or prior restraint. Therefore, the broad discretion vested in the minister of the interior, inherited from the British Mandate, must be judicially structured to balance between this pillar of democratic theory and the perceived need to protect valid interests such as the prevention of breach of the peace or national security. The formula for the appropriate balance, he held, was the probable danger test. Three elements testify to the heavy influence of American law on this opinion. First, the Supreme Court relied on the opinions of Justices Oliver Wendell Holmes and Louis Brandeis for the development of the foundations of the justifications for freedom of expression. Second, the Supreme Court relied on what was at the time the most recent American rendition of the clear and present danger test, found in Dennis v. United States. ${ }^{13}$ The Dennis formula taught that if the government wished to suppress political expression, it had to show that "the gravity of the evil" sought to be averted (e.g., the overthrow of the government with force and violence) "discounted by the improbability that it might occur" was such as to allow official suppression. ${ }^{14}$ Agranat similarly called for an assessment of the "probability" that the danger might indeed occur. This in fact has been the test Israeli courts have applied in 
matters of free expression to this day. ${ }^{15}$ Third, and most important for the development of Israeli constitutionalism, Agranat located the principle of free speech in Israel's Declaration of Independence. ${ }^{16}$ The Declaration, he said, may not be a part of the positive law, but it is the fountain from which all legitimacy flows. It possesses enormous persuasive power. This last move was also peculiarly American, but somewhat more subtle than the previous two. In endowing the Declaration of Independence with interpretive inspiration, Agranat was actually (but not explicitly) relying on the man he held in profound admiration: American Civil War president Abraham Lincoln. In his Gettysburg Address, Lincoln invoked the great legacy of the United States as a nation "conceived in liberty," spoke of the "new birth of freedom," and tied this freedom to democratic values by stating that it was a government of, by, and for the people. Agranat planted these ideas on Israeli soil. The Zionist dream to establish a Jewish state was precisely a dream for "new birth of freedom." Israel was a nation "conceived in liberty," and as such it was dedicated to democratic values. It was an audacious move, quite stunning in the Israeli climate of the 1950s, a move that could not have been imagined by one not immersed in American history and culture. The bold assertion that the purpose of the polity was liberty, and that liberty meant a democratic regime demanding a large measure of free expression, was very American and, in the early 1950s, not widely accepted outside of America's borders. Agranat was confident that Israelis, too, were eager to lift the stone off the well of freedom and to drink the fresh water of liberty.

It is important to emphasize that the importation of American law did not amount to mindless imitation. The best proof lies in the result itself. In the United States of the early 1950s, McCarthyism was roaring, and anybody suspected of harboring sympathy toward communist ideology was labeled disloyal. In Dennis v. United States, the case invoked by Agranat in Kol Ha'am, the US Supreme Court sustained the conviction of the Communist Party leadership. Agranat refused to let the ugly demons of McCarthyism fly over Israeli soil. He indeed adopted the Dennis legal formula but applied it to protect communist speech. Kol Ha'am was allowed to continue its raucous criticism of the government with impunity. A few years later the Israeli Communist Party died a natural death, and its mouthpiece, Kol Ha'am, faded into oblivion.

\section{0s: Yeredor v. Central Elections Committee, 1965}

The case of Kol Ha'am depicted the cleavages of political opinion among the political majority of Jews in Israel, communists included, but Yeredor went to the heart of the Arab-Israeli conflict. ${ }^{17}$ As a result of the bloody war that followed Israel's Declaration of Independence, Israeli Arabs found themselves demoted 
from their status as a majority in the land to that of a minority. In the 1950s, a small group of political activists formed El Ard ("the land" in Arabic), but the group was outlawed by the government. In 1964, members of this group, together with Jewish political activists, formed a political party called the Socialist List and applied to run in the upcoming elections to the Knesset. The government objected on the grounds that five members on the list were also members of the outlawed organization El Ard, suspected of aiming to destroy the Jewish state and restore the status quo ante. The Central Election Committee sided with the government and banned the party. ${ }^{18}$ The question before the Supreme Court was whether Israeli law permitted banning a political party, thereby violating the right to be elected, and by way of extension, whether the right to elect a party of one's choice was also negatively implicated. ${ }^{19}$

The dilemma the Supreme Court faced was that the statute regulating elections did not vest the Central Elections Committee with authority to ban a party. There was no explicit statutory language authorizing the ban. The government was asking the Supreme Court to recognize that it had the inherent authority to ban a political party, or in other words, to make a determination that amounted to judicial legislation.

The Supreme Court, again through Justice Agranat, who by then was chief justice, held that the Central Elections Committee did indeed possess the power to ban a party. ${ }^{20}$ Among other arguments, Agranat relied again on Israel's Declaration of Independence. This time, however, he did not tilt the balance in favor of liberty. He invoked the part of the Declaration that asserted that Israel was a Jewish state and had it trump the freedom of expression. The identity of the Israeli polity, Agranat declared for the first time in a judicial opinion, consisted of a fusion of both Jewish and democratic elements. One could not purge any parts of this formula. No party in the Knesset, he held, could doubt Israel's legitimacy as a Jewish state or advocate its extinction. Because the Supreme Court agreed with the Central Elections Committee that the applicant party intended to deny the legitimacy of Israel as a Jewish state, it concluded that the party could be banned.

This form of legal argument exposes a fundamental difference between Israel and the United States. Indeed, the method of mining the fundamental principles underlying the system was the same-like Abraham Lincoln before him, Agranat invoked the Declaration of Independence to justify his holding. But whereas in the case of Kol Ha'am Agranat pointed to a principle that Israel shared with the United States, the principle of democracy, in Yeredor he allowed a very different principle to take center stage: that Israel is a Jewish state. In American law, one does not find such a substantive ethnic attribute of the American polity that is strong enough to override the democratic process. By contrast, Israel is a country always struggling to balance between the universal and the particular, between 
its commitment to democracy and its determination to remain a Jewish state. In Yeredor the Supreme Court allowed the particular to trump the universal and excluded the Socialist List from the electoral process.

Still, President Lincoln entered the deliberations of the Yeredor case as well. During the American Civil War Lincoln justified the emergency suspension of the writ of habeas corpus without congressional approval, in direct violation of the Suspension Clause found in Article I of the Constitution, as follows: "It forces us to ask: 'Is there, in all republics, this inherent and fatal weakness? Must a government, of necessity, be too strong for the liberties of its own people, or too weak to maintain its own existence?"'21 In other words, Lincoln argued that the safety of the republic justified the temporary suspension of the writ. Here, too, Agranat was implying, violating the equal-protection principle inherent in the election law was justified to protect the Jewish state. In 1985 the Knesset amended the election law to allow the Central Election Commission to ban parties. ${ }^{22}$

It is important to note the differences between the reliance on American law in Kol Ha'am and in Yeredor. In Kol Ha'am Agranat used Lincoln's appeal to the Declaration of Independence to incorporate the principle of free expression into Israeli law. In Yeredor, Agranat used Lincoln's unilateral arrogation of emergency powers to the executive branch to justify the power of the Central Elections Committee to ban political parties. Thus, whereas Kol Häam aligned itself with the more sunny disposition of American constitutionalism, Yeredor opted for the authoritarian, suppressive potential inherent in American constitutional interpretation. Both tracks, indeed, are available for importation. Both American and Israeli laws are complex enough systems to permit such choices. ${ }^{23}$

\section{The 1970s: The Yom Kippur War and the Law of Defamation}

Two years after Yeredor was decided, Israel experienced one of the most traumatic events in its nineteen-year history, an event that came to define its identity to this day. The Six-Day War in June 1967, preceding a most terrifying "waiting period," ended with a glorious victory. Israel emerged as a dominant military power in the Middle East and created the now-intractable dilemma concerning the future of the occupied territories. Under the leadership of Prime Minister Golda Meir, born in Russia but raised in Milwaukee, Wisconsin, US-Israeli relations became cozy. American influence on Israeli politics, culture, and economy was increasingly evident. And yet, while Israelis were basking in the splendor of their military prowess and economic prosperity, they failed to foresee the gathering storm. The 1973 Yom Kippur War, a surprise attack launched 
simultaneously by Egypt and Syria, inflicted severe harm on Israel, tore the people's confidence to pieces, and exposed the country's imminent vulnerability. It also exposed an arrogant and conceited leadership, blind to the writing on the wall. Following intense public pressure, a commission of inquiry was appointed, headed by Chief Justice Simon Agranat, to investigate the causes for "the mishap." At the same time, the United States itself experienced an unparalleled political crisis. Shattered by the failed war in Vietnam and the revelations of massive governmental deceit to keep the war going, Americans were facing the Watergate scandal and President Richard Nixon's disgraceful fall from power. The crown of glory went to the press, which heroically exposed government misconduct and insisted on official accountability. By contrast, the Israeli press at that time was rather smug and complacent. Indeed, Kol Ha'am protected freedom of the press, but Israeli press culture did not take bold advantage of that freedom. Publishers and journalists saw themselves as the long arm of the government and felt comfortable adhering to its strategy and guidelines. Any doubtful voice was silenced by the military censor, acting under the Defense (Emergency) Regulations, which were also inherited from the British Mandate. ${ }^{24}$ Expectations of unity and solidarity shaped the popular understanding of democracy, and aggressive watchdogs were not welcome. After the Yom Kippur War, this self-image began to change. The press observed the American Fourth Estate's vigorous challenges and felt remorseful and inadequate. Israelis were angry with their government, and journalists translated their anger into an increasing willingness to raise serious questions about government policy. When the Agranat Commission began probing the political and military performance that led to the Yom Kippur War, the media coverage became hypercritical and aggressive. ${ }^{25}$ The members of the commission, among them Justices Agranat and Moshe Landau, were not accustomed to this level of aggressive, even acrimonious criticism. As a result, they felt it was only natural to appeal to the minister of justice and to the attorney general to protect them from this watchdog that had suddenly been turned loose. They expected the attorney general to muzzle the press. Herein we see the tensions inside Israeli law related to various paths open to the decision makers. The attorney general could choose the conventional path that Israel had inherited from the British Mandate. This path empowered the government to invoke the law of contempt of court and either punish reporters who "crossed the line" or at least issue a warning that might chill their enthusiasm for criticizing aggressively. The other path was to follow the American model and limit the power of contempt of court because of "the profound national commitment to the principle that debate on public issues should be uninhibited, robust, and wide-open, and that it may well include vehement, caustic, and sometimes unpleasantly sharp attacks on government and public officials." ${ }^{26}$ 
Much to the disappointment of the Agranat Commission, Attorney General Meir Shamgar preferred the American to the English solution. Shamgar's decision to tolerate hostile press coverage inaugurated a new era in the relationship between the government and the press in Israel that was closer to the American model. Israel's press is still rather protective of its government and tends to be deferential in matters of national security, but it is now more self-conscious of its professional duty to keep a critical eye on governmental affairs. ${ }^{27}$

From the perspective of the history of Israel's Supreme Court, the 1970s signaled the end of one era and the beginning of another. Agranat and several of his brethren retired. New justices were appointed, who were either born in or had grown up in Israel, but who eyed the American system of government and its legal culture with appreciation and affection. Shamgar, the attorney general who valued the freedom of the press, joined the Supreme Court and in 1983 would be appointed chief justice. Meanwhile, Yitzhak Rabin, architect of the victory in the Six-Day War and an admirer of the American constitutional system, particularly the strong powers vested in the president, was now prime minister. Rabin's new attorney general, Aharon Barak, the outstanding former dean of the faculty of law at Hebrew University who had spent time at Harvard Law School, would also soon join the Israeli Supreme Court. Barak would succeed Shamgar as chief justice in 1995. These two men are pivotal to the continuation of our story because of their determination to pursue the path Justice Agranat took in 1953 and further consult American jurisprudence, particularly that related to freedom of expression. ${ }^{28}$

Back to freedom of expression in Israel of the 1970s. As a junior justice in the mid-1970s, Shamgar attempted to modify the Israeli law of defamation by incorporating into it the important 1964 holding in New York Times v. Sullivan. ${ }^{29}$ In that case, a unanimous US Supreme Court held that when public officials sue the press for defamation, the First Amendment operates as a shield to protect the journalist. To succeed in a defamation claim, the public official must prove that the journalist had actual knowledge that the report was false or exercised reckless disregard of the falsehood (the doctrine known as the "actual malice" rule). This holding has been recognized as one of the cornerstones of First Amendment law in the United States and has survived both the conservative Burger and Rehnquist courts. ${ }^{30}$

The Israeli case Hairetz v. Electric Company involved the CEO of a governmental company. ${ }^{31}$ The director was criticized for authorizing the electric company to purchase for him an expensive American car with fancy amenities. The purchase occurred during a time of economic recession in Israel. Following public outcry, the director announced that he would sell the car, but he appeared to take his time. The newspaper Ha'aretz criticized this state of affairs, and the electric company sued, claiming that the director's reputation was injured. In 
court, Shamgar interpreted the Israeli defamation law in light of New York Times v. Sullivan; he even provided the same justifications that Justice William Brennan provided in his American opinion. Justice Shamgar's opinion prevailed in the first round, but Israel's court then decided to invoke a procedure called "further hearing," which allowed reconsideration of a ruling with an expanded panel of justices. Five justices now reconsidered the case, and Shamgar found himself dissenting. Writing for the majority, Justice Landau, then deputy chief justice and soon to be chief justice, held that the Israeli law of defamation was closer to the British model than to the American model. Therefore, a firm distinction between facts and opinion required that facts journalists reported must be correct. Only a "fair comment" or opinion was immune to a lawsuit by the public official. The enlarged panel found Ha'aretz, the leading daily at the time, liable for defamation. By historical accident, the matter came before the Israeli Supreme Court as the Nazi Party in Illinois was litigating its right to march in the town of Skokie. The town was populated by Holocaust survivors who strongly opposed the idea that Nazis could be allowed to march in their streets. Both the state and the federal courts refused to carve an exception to the principle that the First Amendment insisted on content neutrality, and did not allow a municipality to silence a view, no matter how reprehensible. ${ }^{32}$ Justice Landau was shocked. As he rejected Shamgar's view and held that Ha'aretz had defamed the director of the electric company and owed him compensation for injuring his reputation, Landau added, "[Skokie] was decided because the Justices saw themselves bound by the First Amendment. We should better reflect on that phenomenon."33

The Landau-Shamgar debate brought to the surface the ever-present tension within the Israeli legal community. One camp, represented by Landau, preferred a cautious path loyal to the English common law, which values order and civility over social dynamism, and therefore would opt for a more restrained public debate. The other camp, represented by Shamgar, wished to encourage Israeli development into a vibrant, energetic democracy, willing to risk some cacophony to allow a wider spectrum of views and ideas and encourage accountability and transparency. We shall return to this point below.

\section{The 1980s: Kahane Comes to Israel}

The 1980s intensified the tension between the two camps. An American-born rabbi named Meir Kahane forced the Israeli polity to make a choice in at least one area: racist speech. ${ }^{34}$ Kahane was a relatively well known figure in New York Jewish circles. He founded the Jewish Defense League, an organization prone to violence, feeding on the tension between Jews and African Americans at the end of the 1960s. He also attracted public attention through his fight on behalf 
of Soviet Jewry. In 1971, Kahane immigrated to Israel, settled in the occupied territories, and became politically active. His agenda included a racist component: he advocated an Israel populated by Jews alone, considered Israeli Palestinians as "others," and encouraged ethnic discord. Although Jewish-Israeli prejudice against Palestinian Arabs was a part of Israeli society prior to Kahane's arrival in Israel, his charismatic presence and daring tactics considerably aggravated Jewish-Arab relations. The 1980s saw several legal battles concerning the legitimacy of racist speech in Israel, mostly related to Kahane and his followers. By and large, the courts favored wider latitude for free speech, whereas the Knesset and other government institutions favored curbing racist speech. In 1985, the Knesset amended Section 7 of Basic Law: the Knesset, to ban political parties that incite racism. ${ }^{35}$ Another amendment to the Knesset's procedure prohibited submission of a bill that contained racist language..$^{36}$ In 1986, racist speech became a criminal offense punishable by a five-year prison term. ${ }^{37}$ Israel's Knesset preferred to follow the example of Europe and the United Kingdom, jurisdictions that banned racist speech, rather than that of the United States. ${ }^{38}$

Comparing the Israeli activity in this area to that obtaining in the United States allows us to assess the extent and the limits of American influence on Israeli law. Today racist speech, as distinguished from hate crimes, is largely protected under the First Amendment. ${ }^{39}$ That has not always been so. In 1952, the US Supreme Court held that a state acts within its police powers when it bans racist speech. ${ }^{40}$ Thereafter, the Court expanded the protection of speech, even to racist speech, but at the same time expanded civil rights. ${ }^{41}$ Consequently, for a while Americans thought the civil rights movement had won and racism was a thing of the past. ${ }^{42}$ During the 1980s some legal scholars began to argue that "words wound" and that therefore regulating racist speech should be permissible. ${ }^{43}$ This debate was taking place at precisely the same time the Israelis were deliberating this question. The Israeli Supreme Court, in several opinions involving Kahane, ruled that freedom of expression should prevail. As we saw, however, the Knesset was of a different opinion. ${ }^{44}$ We see a fundamental difference between the US and the Israeli constitutional systems. In Israel, as in the United States, the Supreme Court has great power to interpret statutes and influence the legal culture. However, the Israeli Knesset does have the final say. If the members of the Knesset form a majority, their votes prevail and their legislative judgment overrides that of the Supreme Court. Not so in the United States. In both Israel and the United States, racism is a fact of life and has been found to be toxic. Both polities attempted to curb it through the law. The movement to outlaw racist speech succeeded in Israel but failed in the United States, where neither Congress nor state legislatures may trump the Supreme Court's interpretation of the Constitution. ${ }^{45}$ Only a constitutional amendment, which is achieved through a difficult and rarely successful process, may do so. 
But if in the matter of regulating racist speech Israel deliberately chose a different path and criminalized racist expression, in the matter of censorship it exhibited a more marked willingness to adopt US ideas. Two important cases of the 1980s display this point.

Yitzhak Laor is a noted Israeli poet and writer. In the early 1980s he wrote a play titled Ephraim Goes to the Army. The play scratched an open wound: the performance of Israeli soldiers in the occupied territories. In sharp and poignant dialogue, the play denounced Israeli brutality against the Palestinians. ${ }^{46}$ The Film and Theater Censorship Board, a relic of the mandatory period, was outraged by the play and banned its production. The 1984 opinion in Laor v. Film and Theater Censorship Board overturned the ban and has become a landmark case. ${ }^{47}$ Interestingly, the Censorship Board internalized the Kol Ha'am test and argued that the "probable danger" doctrine, rather than the bad tendency test or some "reasonable" yardstick, was the appropriate legal tool by which to evaluate the ban. The board found depicting Israelis as brutal occupiers, even resembling Nazis, both inflicted immeasurable pain on the Jewish population and created a probable danger that Palestinian Israelis would resort to violence. Again, the reader may ask herself if the social, political, and historical differences between the United States and Israel warranted a different judicial approach. Was it relevant that the US population did not suffer the emotional proximity to the trauma of the Holocaust that Israelis experienced? Or that Americans are not familiar with a domestic occupation and, furthermore, since 1971 American males have not been obliged to perform military service? Still, Americans have experienced the trauma of slavery, of Jim Crow laws, and of extensive lynching and yet remained loyal to the principle of free expression. The Israeli Supreme Court must have felt that the American principles, rooted in the theory of democratic self-government, should serve Israel as well. The Supreme Court made several references to American law, quoted both American scholars and judicial opinions, and emphasized three important American constitutional doctrines. First, the Supreme Court emphasized the need to apply a balancing of interests test that would be structured so that the value of free speech would be appropriately assessed. Second, the Supreme Court emphasized that it would review the facts de novo rather than defer to the judgment of the Censorship Board when free expression was at stake. Third, the Supreme Court made use of the means/ends relationship prong of the strict scrutiny test, often applied by US courts when a constitutional right is allegedly violated. The Supreme Court held that if a less drastic means was available to the decision makers, they should not resort to censorship. None of these devices was new to Israeli law. The innovation lay in the subordination of the Film and Theater Censorship Board to the jurisprudence of free expression and in the factual context. The future of the occupied territories has been an increasingly contentious question 
in Israel. Israelis wished to think of the government in the West Bank as "enlightened occupation," and the play meant to specifically puncture this belief. The Supreme Court's opinion, therefore, touched a raw nerve, but evidently the justices felt that Israelis were mature enough to overcome the indignation and permit a climate of free expression. The Knesset eventually abolished the Censorship Board related to theatrical plays. Today only film censorship survives. We shall return to this issue when we address cases of the twenty-first century. ${ }^{48}$

A 1988 case seals the trilogy for this decade. Laor presented the army in a very unfavorable light. But even though the play walked a fine line between fact and fiction, it was still theater, and portrayed low-level officers. The case resulted in limitations on the board, an archaic body about which Israelis did not care much. Shnitzer v. the Military Censor was an altogether different matter. ${ }^{49}$ It involved an institution at the heart of the security establishment: the mythical Mossad. It challenged the authority of the military censor, until then an authority quite immune to popular scrutiny. An article by Aluf Ben, then a young, irreverent reporter and today Ha'aretz's editor-in-chief, discussed recent dissatisfaction among the Mossad upper echelons, and situated the upcoming appointment of a new Mossad chief in the context of this discontent. The article also wished to name, and describe, the head of the Mossad, until then inaccessible to public scrutiny, and only known by his first initial. ${ }^{50}$ In accordance with the law, the article was submitted to the military censor, who repeatedly banned publication. $H a^{\prime} i$, a local magazine and a part of the Ha'aretz group slated to publish the piece, petitioned the Supreme Court. The question was, To what extent was the press entitled to tell the Israeli people the truth about one of their central institutions? In a unanimous opinion of three justices, Chief Justice Barak held that the military censor, like the rest of the executive branch, was subject to judicial review. The censor was obliged to apply the "probable danger test" before he could censor journalists. In a review de novo, the Court examined the article and decided that the probable danger test was not met and that therefore the magazine was entitled to publish the piece. The Court relied heavily on the 1953 case of Kol Haim and other Israeli precedents. The landmark American case involving the Pentagon Papers also made an appearance, and one has a feeling that the Israeli Supreme Court was eager to adopt its spirit and approach. ${ }^{51}$ The Pentagon Papers case rejected the Nixon administration's request for an injunction against the Washington Post and the New York Times when the two newspapers began to publish top-secret documents related to the Vietnam War. The case pushed the envelope in its insistence on accountability and transparency in government and in allowing the people access to the belly of governmental operations. The Israeli Supreme Court must have been proud of its bold move, placing Israel squarely in the camp of vibrant Western democracies, eager to nurture the principle that the ruled must keep watch over their rulers. 


\section{The 1990s: Basic Law-Human Dignity and Freedom and the Assassination of Yitzhak Rabin}

We must now divert from our narrative to flag two important constitutional events in the 1990s that are indirectly connected to freedom of expression: the passage in 1992 of Basic Law: Human Dignity and Freedom and the assassination of Prime Minister Yitzhak Rabin in 1995.

This law raises important questions: First, are the rights it recognizes more privileged than those rights it fails to mention? Second, does the law confer upon the courts the power to invalidate subsequent legislation that violated the rights recognized therein? In other words, does the new Basic Law confer upon the courts the power of judicial review? ${ }^{52}$

The Basic Law does not mention the right to freedom of expression or the right to equal protection of the laws, which is an important subject that is not addressed in this chapter. The original plan was to submit to the Knesset additional but separate Basic Laws that would guarantee freedom of speech and freedom of association. In all probability this plan aimed to prevent the legislation from becoming contentious and to enhance the chance that the Knesset would adopt a bill guaranteeing at least some rights. ${ }^{53}$ The lesson for the reader is that to the extent that the Knesset looks to the United States for inspiration, it picks and chooses from that legacy what it wishes to adopt. The US Bill of Rights begins with the First Amendment. Israel's Knesset kept its silence about free speech, neither endorsing nor rejecting the right. This does mean that the pull of American culture notwithstanding, Israelis are marching to their own drummer. Some have suggested that the right to freedom of expression may be "found" in the concept of human dignity, which is the cornerstone of Basic Law: Human Dignity and Freedom. We shall return to this issue momentarily.

Another central question relates to judicial review. Did the Basic Law endow the courts with the power to invalidate legislation ${ }^{54}$ It was certainly silent on this issue just as the US Constitution was silent when William Marbury sued James Madison over the withholding of his commission to a judgeship. In Marbury v. Madison, now a cornerstone of American constitutional law, Chief Justice John Marshall determined that the federal courts did possess the power to invalidate legislation if they concluded that it violated the constitution. No one has doubted this proposition ever since. ${ }^{55}$ In 1992, Chief Justice Aharon Barak gave a speech later published under the title "The Constitutional Revolution." He suggested that the Basic Law created a Bill of Rights and conferred upon the courts the power of judicial review. Soon thereafter, in Bank Hamizrahi v. Migdal, a panel of nine justices accepted Barak's idea and held that Israeli courts could invalidate legislation that violated the Basic Law. ${ }^{56}$ The fingerprints of Marbury 
v. Madison, as well as the two centuries of American debate, make a strong presence in this case. The terms "judicial activism" and "judicial restraint" entered the Israeli legal menu, and any Israeli law student feels at ease discussing their pros and cons. ${ }^{57}$

The other central event in the 1990s was the assassination of Prime Minister Yitzhak Rabin on November 4, 1995, at a peace rally in Tel Aviv. The assassination of the prime minister, hero of the Six-Day War, and architect of the Oslo peace process by a young man who hoped he would thereby undermine Rabin's policies was an earth-shattering event. It ignited a fierce debate about the contours of free speech in Israel and the distinction between protected expression and incitement. In the aftermath of the assassination, the Israeli law of incitement has been amended several times to reflect the Knesset's fear that the principle of free expression might be used by undemocratic or nationalist forces who do not value the principles of democracy. The same debate was repeated during the prime ministership of Ariel Sharon when plans for evacuating settlements from the Gaza Strip were carried out. It is quite likely that we have not seen the end of this debate and that the political turmoil accompanying any decision about the future of the occupied territories will bring about renewed calls for a vigorous application of the criminal law against incitement, countered by defenders of free speech. ${ }^{58}$

Basic Law: Human Dignity and Freedom made an appearance in a highly controversial case, symbolically concluding the twentieth century. It had to do with the Holocaust, memory, history, and Zionist ideology. It also raised questions about postmodernism, the relativity of truth, and whether a sharp line between fact and fiction must be preserved even at the expense of artistic freedom. Hannah Senesh has been a mythical figure in Israel and in the Jewish world. ${ }^{59}$ A young woman, a budding poet, and a courageous soldier, she was recruited by the British to parachute behind enemy lines in Hungary and make contact with the remnants of the Jewish community then being transported by Adolf Eichmann to the death camps. She was caught by the Gestapo, tortured, and executed. In Israeli mythology she stands for noble heroism. Furthermore, she is contrasted with Rudolf Kasztner, leader of the Jewish community in Hungary, who many suspected of collaborating with the Nazis. ${ }^{60}$ Motty Lerner, a playwright, wrote a play about the Kasztner affair and included a statement by Kasztner that Senesh broke under aggressive interrogation and gave away the names of her fellow paratroopers. The question before the Supreme Court was whether Senesh's brother, Giora, had the right to enjoin Israel's Broadcasting Agency, which is a governmental institution, from including the statement in the play. It should be emphasized that Lerner and the Broadcasting Agency attached an announcement that the play was a work of fiction, a docudrama. Giora Senesh argued that even a fictional assault on his sister's memory was intolerably 
painful and should not be permitted. In a 2-1 opinion, the Supreme Court declined to order the Broadcasting Agency to delete the damaging statement. ${ }^{61}$

The entire Supreme Court agreed that Senesh was not broken during the interrogation and did not divulge the names of her comrades. This proved to be an important pillar of the opinion. The basic Zionist narrative was confirmed by the Supreme Court. Because the Supreme Court expressed confidence in Senesh's heroism, it was free to pose her fight for freedom in Nazi-occupied Europe as compatible with, rather than antithetical to, the freedom of expression that her brother's petition attacked. The Senesh Court, therefore, did not confirm the stain on Senesh's reputation, but rather augmented Senesh's struggle to free the world from tyranny, any tyranny. Barak's first step was to anchor the right to freedom of expression in Israeli law. Without analyzing the question, Barak assumed that the term "human dignity" in Basic Law: Human Dignity and Freedom included freedom of expression. He also enlisted canonical precedent (Kol Haiam), the deepest roots of Jewish culture (prophecy as a phenomenon of speaking truth to power), and the dual nature of Israel as a Jewish and democratic state. ${ }^{62}$ These three fundamental arguments are all authentically Israeli and rather independent of American influence. Together they prove the level of maturity and confidence that the Israeli judiciary had reached at that point, skillfully using the tools in the arsenal of the polity itself to resolve significant questions.

However, America was peeping behind the veil in subtle and less subtle ways. The Kol Haim case itself, as discussed above, was based on considerable US intellectual sources. It is indeed interesting to see how it has now been detached from its mooring in US law and culture and has attained an Israeli life of its own. American legal influence was apparent as well. The Israeli Supreme Court quoted Justice Brennan's famous statement in New York Times $v$. Sullivan that speech must be "uninhibited, robust and wide open." ${ }^{63}$ Later it also quoted Justice Brandeis's equally famous statement in Whitney $v$. California that "only an emergency justifies repression." ${ }^{64}$ More important, the Supreme Court held that the legal analysis at hand required balancing. The right to free expression had to be balanced against the person's right to dignity and reputation, as well as against the interest of the public in avoiding a breach of the peace. The tool of "balancing" basic values and interests was deployed by Justice Brennan in New York Times v. Sullivan and has influenced American constitutional law since the New Deal. One of its most famous proponents on the US Supreme Court was Justice Felix Frankfurter. Then, and now, the tool of balancing has been controversial, and lately it has been emphatically rejected by Justice Antonin Scalia but embraced by Justice Anthony Kennedy ${ }^{65}$ In the Senesh case, Chief Justice Barak, true to his jurisprudential philosophy, had taken a stand in favor of balancing and against a formalistic approach to constitutional law. Today, balancing has permeated Israeli constitutional analysis so extensively that its roots in American jurisprudence are nearly forgotten. ${ }^{66}$ 
It is interesting, at this point, to reflect on the Senesh case in the company of Ha'aretz v. Electric Company, decided in the 1970s ${ }^{67}$ In Haaretz, the Supreme Court upheld truth as a cherished value, opined that the right to reputation is as important as the right of the press to criticize public officials, and boldly distanced itself from the American idea that uninhibited speech is good for democracy. The Senesh majority rejected this view, thereby embracing the American position. But Senesh also included a strong dissent by Justice Mishael Cheshin. This dissent, along with the fact that public pressure propelled the Broadcasting Agency to delete the controversial paragraph, may indicate that underneath the surface there are forces in Israel who feel uncomfortable with this level of freedom and prefer a higher level of regulation of speech. This discomfort is related not only to matters concerning national security, but also to matters of history and culture.

As mentioned above, the decision in the Senesh case was delivered in 1999, thereby symbolically bidding farewell to the twentieth century. That same year, at the dawn of the new century, Chief Justice Barak delivered another critical opinion for the Supreme Court, denying the power of Israel's security services to engage in torture without explicit Knesset authorization. ${ }^{68}$ Could he be thinking of the techniques applied against Hannah Senesh, a young woman noble and pure? At the time, Israel's battle against terrorism did not touch the American nerve, but soon enough, with the trauma of September 11, 2001, the question of torture came to haunt Americans. They became interested in the Israeli experience. Herein appears a reverse phenomenon: Israeli influence on American law. Barak's opinion has been studied by American legal scholars and judges as they contemplated an answer to the question of whether the US Constitution might be interpreted to permit torture. ${ }^{69}$

\section{The First Decade of the Twenty-First Century}

Terrorism continued to be a very serious problem for Israel in the first decade of the twenty-first century. This review concludes with two cases dealing with varieties of censorship in the context of the war against terrorism: one decided in 2003 following Operation Defensive Shield, and the other decided in 2009 as Operation Cast Lead came to an end.

By then, Chief Justice Barak had retired from the bench. His impact on the legal system of Israel, and in particular on the value of free expression as interpreted in the Israeli context, had been immense. Barak had also kept close ties with the United States and had been very familiar with its legal system. He was replaced by Chief Justice Dorit Beinisch. It is interesting to note that while the Supreme Court of Israel was dominated exclusively by males until 1974, it has 
been much more open to the nomination of women than the US Supreme Court. Today, in addition to Chief Justice Beinisch, four women serve on the Supreme Court, compared with the three women now serving on the US Supreme Court. ${ }^{70}$ The two opinions reviewed below were written by women.

A suicide bomber exploded amid innocent civilians celebrating the Passover Seder at a hotel in the town of Netanya. Many were killed and more were wounded. It was one more deadly attack in a string of suicide bombings. In retaliation, Israel launched Operation Defensive Shield. ${ }^{71}$ A particularly fierce battle ensued in the refugee camp located in the West Bank town of Jenin. Scores were killed and wounded on both sides, and the destruction was immense. On the heels of the battle, an Palestinian-Israeli filmmaker, Muhammad Bakri, visited the site with the intent of giving voice to the Palestinian side of the story. His film, Jenin Jenin, was a blood-chilling "J'accuse" against the Israeli military. ${ }^{72}$ In accordance with Israeli law (recall that following Laor, discussed above, the board of censorship of theatrical plays was abolished but the board of film censorship was retained), ${ }^{73}$ the Board of Film Censorship convened, deliberated, and banned the film. The film director petitioned the Supreme Court, and the ban was invalidated. The board argued that the film posed "a danger to the public peace and its feelings." ${ }^{\prime 4}$ The main point around which the arguments revolved was that the film placed Israel and the individual soldiers fighting on its behalf in an extremely offensive and odious false light, and that it was based not on facts but on lies and misrepresentations.

The three justices of the panel, Dalia Dorner, Ayala Procaccia, and Asher Grunis, indeed agreed that the film was offensive and that it did not reflect the truth. However, they insisted that the board did not have a monopoly on the truth, and its function is not to shield the Israeli public from falsehoods. Although the Supreme Court rejected the filmmaker's argument that the statute authorizing the censorship board was unconstitutional, ${ }^{75}$ it applied the limitation provision of the Basic Law and found that the ban was not applied for a legitimate purpose, and furthermore was not proportional. ${ }^{76}$ The reasoning of the Supreme Court made it clear that it was well aware of the changes in the media environment in the twenty-first century. It pointed out that the board had no power to prevent the showing of the film outside of Israel, and that in the age of globalization and the Internet, anyone willing to pay $\$ 30$ (note that the court used the currency of the American dollar, not the Israeli shekel) could purchase the film. The Supreme Court opined that validating the ban might even invite the suspicion that Israel was trying to hide something from international public opinion, and thus might tarnish Israeli reputation further rather than defending its name. From the perspective of American influence on Israeli law, this is an interesting point. Furthermore, the fact that American public opinion is so crucial for Israel's well-being appears between the lines. It was the American sweeping 
revolution in technology that turned the world into a global village and made the film available for all to purchase and watch. American technology thus made the act of banning futile and even self-defeating. ${ }^{77}$ From this practical perspective, it was not even necessary to use American law to reach the result. American pragmatism was enough.

As we have seen, the Court in Jenin Jenin did not need American law to justify an antipathy to censorship. It already had its own long line of precedents, starting with Kol Ha'am, and it had Basic Law: Human Dignity and Freedom to guide it in evaluating the legality of governmental action. But the Jenin Jenin Court did invoke American cases. Justices Holmes and Brandeis's dissents reappeared, and their famous quotes were on full display. Justice John Harlan's seminal opinion in Cohen v. California was also invoked to express "the hope [recall that Israel's national anthem is "The Hope"] that use of such freedom will ultimately produce a more capable citizenry and a more perfect polity." ${ }^{78}$ But it should be emphasized that along with the discussion of US law there were also discussions of English and Australian law. ${ }^{79}$ This fact displays another difference between Israeli and American law. In the United States there is currently a raging debate about the usage of foreign law. Some even argue in favor of amending the Constitution to prohibit the tool of consulting foreign law. ${ }^{80}$ In this respect, Israelis are closer to their continental relatives; they are curious and open, willing to consult any legal solution to the problem at hand. ${ }^{81}$

Two final anecdotes embedded in the Jenin Jenin opinion help us reflect on the American/Israeli connection. One of the US Supreme Court justices quoted by Justice Dorner was Justice William O. Douglas, speaking in 1949 in Terminiello v. Chicago. ${ }^{82}$ Terminiello, an anti-Semitic priest, vexed the Jewish community in Chicago with his offensive remarks against Jews. On the heels of the Holocaust, these remarks sparked rage and indignity. The US Supreme Court invalidated the priest's conviction for breach of the peace, with Justice Douglas speaking for the majority. Shortly thereafter, Justice Douglas visited Israel and met with the justices of the newly established Supreme Court. "Didn't you go too far in Terminiello?" asked the Chicagoan Justice Agranat. Justice Douglas retorted, "We can afford it. Can you?" 83 Agranat commented that this answer reverberated in his mind for many years to come. Almost fifty years later, in Jenin Jenin the circle was closed. When Justice Dorner was quoting Douglas in Terminiello, she was also advising that "we can afford it." Indeed, Israel has come a long way since its establishment in 1948. Justice Procaccia, the other woman on the panel, ended her splendid concurring opinion with another quote, from the most famous legal celebrity in America: Alan Dershowitz. The Harvard law professor is not only prolific but also extremely influential in both the United States and Israel. His quote, strategically placed at the end of Procaccia's opinion, advised, "The solution is to answer bad speech with good 
speech, and to have the good speech prevail in the marketplace of ideas." ${ }^{\prime 4}$ Dershowitz is one of Israel's most eloquent and persuasive defenders. Was Justice Procaccia saying that with friends like these, we do not need censorship? That his extraordinary advocacy would combat the impact of Jenin Jenin? That here we have an illustration of what Justice Brandeis meant by saying "more speech" is the best cure for "noxious doctrine"?

The final case in this review ends the first decade of the twenty-first century: Society of Foreign Journalists v. Minister of Defense. The journalists, presumably Americans among them, sought access to the Gaza Strip before, during, and after Operation Cast Lead. The Supreme Court rejected their petition but expressed satisfaction with the government's statement that access would be guaranteed. The opinion was very short and did not rely on any precedents. No one would have expected a different outcome. One cannot expect the judiciary to interfere in security considerations as war is raging. ${ }^{85}$ Clearly the American military would not grant more access to journalists in either Iraq or Afghanistan. The interesting American fingerprint on the opinion is related to language. Israelis are proud of their Hebrew. They flag it as one of the most durable and valuable achievements of Zionism. And yet Hebrew is permeated with foreign terms. Here Chief Justice Beinisch describes the Supreme Court's contribution to the negotiations between the journalists and the military: "We offered [the government] to consider the 'pool' system as a solution to granting access.... The government stated that ... it will allow the entrance of eight foreign journalists . . . applying the 'pool' system." Indeed, the word "pool" appears between quotation marks, as if to indicate that it does not belong. The chief justice was writing a short opinion spontaneously and in a great hurry, without taking the time to check whether there was a Hebrew translation for the term. But she did seem comfortable using American English in her opinion, while not feeling the need to rely on any American source. This, too, reveals American influence on Israeli law. ${ }^{86}$

\section{Conclusion}

The second decade of the twenty-first century is barely upon us, and therefore it is premature to analyze any emerging trends in the field of free expression. It is, however, important to mention briefly two recent developments. First, the ubiquitous presence of technology as well as the Internet resulted in what has come to be known as the Anat Kam affair. Kam, a soldier, surreptitiously obtained classified documents from her military office and shared them with Ha'aretz reporter Ury Blau. In 2011 Kam was convicted of espionage. It is not yet clear whether Blau will be indicted for revealing the content of classified 
documents. It remains to be seen whether this episode results in a reaffirmation of the rationale of the Pentagon Papers case or in a more restrictive jurisprudential approach that insists on the limits of free expression when balanced against national security concerns. ${ }^{87}$ American influence may affect the Israeli courts as they confront this issue, but it is important to realize that in the United States itself the issue of how to deal with the leakage of classified documents is extremely controversial.

The second phenomenon that may come to characterize the second decade of the twenty-first century has a more distinct Israeli flavor. It has to do with a wave of legislation and legislative activity (bills not passed or bills pending) that does not directly address freedom of expression yet indirectly chills the freedom of speech. One example is the Nakba Law, passed in March 2011, which empowers the minister of finance to curb governmental funding of institutions commemorating the Palestinian trauma rooted in the 1948 war. If this legislative agenda gains momentum, Israeli democracy may embark on a path more in keeping with the McCarthy era in the United States and less with the progressive spirit of the United States, associated with James Madison, Thomas Jefferson, and Louis Brandeis. ${ }^{88}$

There is a basic tension within Zionism that nurtures all aspects of Israeli society and culture, including law. It is a tension between Utopian Zionism and Catastrophe Zionism. In a nutshell, Utopian Zionism reflects the idea of Israel as a light unto the nations, a state based on universal values and guided by moral principles, in accordance with the vision of the great biblical prophets of Israel. This idea is specifically stated in the Israeli Declaration of Independence and permeates early Zionist thought. ${ }^{89}$ Judicial opinions invoking the soaring confidence that freedom of speech will lead to better citizenry and a better polity capture the ideals of Utopian Zionism. Catastrophe Zionism, rooted in the historical experience of persecution, defenselessness, and isolation culminating in the Holocaust, yield an Israel guided by the particular rather than the universal: it is a nation dominated by the overwhelming urge to survive, and therefore subordinates all other considerations to the supremacy of survival. In biblical terminology, this worldview is captured as "a people that dwells alone and shall not be reckoned among the nations." ${ }^{\prime 0}$ Judicial opinions influenced by this vision emphasize security above other values, aggressively defend the classical Zionist narrative, and view dissent as disloyal and subversive. Good examples are the decisions by the censorship boards in Laor and Jenin Jenin versus the Supreme Court's opinions in these cases, which agreed that the play and film, respectively, were offensive, and yet held that they should be protected under Israel's constitutional umbrella. A similar tension is played out as this chapter is being written, between those who would like to chill the speech of Israeli professors critical of Israel, and those who insist that Israel must tolerate and respect their right to speak. ${ }^{11}$ 
It is hard to predict how this clash will unfold. As described in this chapter, Israel has gone a long way toward protecting and tolerating even the most painful criticism. This trend may well be reversed, however. In making the decision of whether to maintain the current climate of freedom or to embark on a suppressive path, Israel will not necessarily consult other legal systems. Long are the days since the leadership of the Yishuv, in the days before statehood, eyed Americans with critical reserve. So, too, gone are the days when American free speech jurisprudence served as a model for Israelis to look up to and to emulate. By now Israel is quite mature, and has enough assets in its own library to guide it through difficult times. American law is still very interesting to Israelis, but it no longer plays the crucial role it played in the first decades of statehood.

\section{Notes}

1. I use the term "split family" both metaphorically and empirically. Many members of the Zionist elite in Palestine had relatives in the United States. Examples include David BenGurion, Golda Meir, Berl Katznelson, and Moshe Dayan. See, for example, Deborah Dash Moore and I. S. Troen, Divergent Jewish Cultures: Israel and America (New Haven, CT: Yale University Press, 2001).

2. For law during the Mandate period, see Ron Harris, et al., The History of Law in a MultiCultural Society: Israel, 1917-1967 (Hants, England: Ashgate Publishing, 2002); Assaf Likhovski, Law and Identity in Mandate Palestine (Chapel Hill: University of North Carolina Press, 2006).

3. For a full list of the Basic Laws, see http:// knesset.gov.il/description/eng/eng_mimshal _yesod1.htm. For an interesting overview, see A. Gross, "Global Values and Local Realities: The Case of Israeli Constitutional Law," in Toward a Universal Law for Humanity, ed. D. Davis, A. Richter and C. Saunders (Oxford: Hart Publishing, forthcoming).

4. An entrenched provision in a Basic Law would typically require a supermajority ( 80 out of the 120 members) or an absolute majority (61 members). Compare with Article V of the US Constitution, which requires that a proposal to amend be adopted by a two-thirds majority of both houses of Congress and ratified by a three-fourths majority of the states. Article $\mathrm{V}$ also stipulates that no state shall lose its equal representation in the Senate without its own consent.

5. For the emergence of judicial review of legislative action, see below, p. 201, and A. Rubinstein and B. Medina, The Constitutional Law of the State of Israel (Tel Aviv: Shocken, 2008), and references there. See also Pnina Lahav, "Israel's Supreme Court" in Contemporary Israel: Domestic Politics, Foreign Policy, and Security Challenges, ed. R. Freedman (Boulder: Westview Press, 2009).

6. Gad Barzilai, “The Ambivalent Language of Lawyers in Israel: Liberal Politics, Economic Liberalism, Silence, and Dissent," in Fighting for Political Freedom, ed. T. C. Halliday et al. (Oxford: Hart Publishing, 2007), pp. 247, 247-249. See also Pnina Lahav, "American Moment(s): When, How, and Why Did Israeli Law Faculties Come to Resemble Elite US Law Schools?" Theoretical Inquiries in Law 10 (2009): 653.

7. David Rabban, Free Speech in Its Forgotten Years, 1870-1920 (Cambridge: Cambridge University Press, 1999).

8 . Through the process of incorporation, which began with Gitlow v. New York, 268 US 652, 666, 45 S.Ct. 625, 630 (1925).

9. See 2010 term, Roberts Court, for example, Citizens United v. Federal Election Commission, 558 US 50 (2010), and United States v. Stevens, 130 S.Ct. 1577 (2010).

10. Space does not allow a thorough review of the Israeli case law. Though I tried to focus on the most significant cases, it is quite possible 
that others may disagree with my choices and place the emphasis on additional cases not herein reviewed. For further study, see David Kretzmer, "The Influence of the First Amendment Jurisdiction on Judicial Decision Making in Israel," in Constitutional Bases of Political and Social Change in the United States, ed. Shlomo Slonim (New York: Praeger, 1990), p. 295; and A. Reichman, "The Voice of America in Hebrew? The Reliance of Israeli Courts on American Jurisprudence in Matters of Freedom of Expression," in Be Quiet, Someone Is Speaking, ed. Michael D. Birnhack (in Hebrew; Tel Aviv: Tel Aviv University Faculty of Law, 2006). Haayin Ha-Shvi'it, a website covering the Israeli media, has extensive coverage and a bibliography of matters related to the press in Israel, www.the7eye.org.il/Pages/home.aspx; the human rights portal at www.humanrights.org.il /main.asp?MainCategoryID $=5$ reviews cases related to freedom of expression (all in Hebrew). See also discussion in Rubinstein and Medina, Constitutional Law of the State of Israel, and references there; and discussions in David Kretzmer and Francine Kershman Hazan, Freedom of Speech and Incitement Against Democracy (Netherlands: Kluwer Law International, 2000); Gary Jeffrey Jacobsohn, Apple of Gold: Constitutionalism in Israel and the United States (Princeton, NJ: Princeton University Press, 1992); Aharon Barak, The Judge in a Democracy (Princeton, NJ: Princeton University Press, 2008); and Moshe Negbi, Freedom of the Press in Israel: Values in the Legal Mirror (in Hebrew; Jerusalem: Jerusalem Institute for Israel Studies, 1995).

11. HCJ 73/53, 87/53, Kol Ha'am Ltd. v. The Minister of Interior [1953], 7 PD 871 (in Hebrew), I Selected Judgments of the Supreme Court of Israel 90 (1948-1953) (in English). See Pnina Lahav, Judgment in Jerusalem: Chief Justice Simon Agranat and the Zionist Century (Berkeley: University of California Press, 1997), pp. 107-112. See also Orit Rozin, "Kol Häam: A Portrait of a Struggle," in Birnhack, Be Quiet, Someone Is Speaking, p. 71.

12. Kol Ha'am Ltd. v. Minister of Interior (known as the first Kol Ha'am case).

13. Dennis v. United States, 341 US 494, 507 (1951).

14. Ibid., p. 510.
15. The term "probability" was translated into Hebrew as "near certainty", and this is how it appears in English translations of Israeli opinions. However, the reader should keep in mind that "near certainty" is not an independent Israeli construct, but rather the Hebrew translation of "discounted by its improbability."

16. The official title is "The Declaration of Establishment of the State of Israel," but it is popularly referred to as the Declaration of Independence. For the American origins of the Declaration, see Y. Shachar, "Jefferson Goes East: The American Origins of the Israeli Declaration of Independence," Theoretical Inquiries in Law 10 (2009): 589.

17. Elections App. 65/1 Yaakov Yeredor v. Chairman of the Central Election Commission for the Sixth Knesset [1965], 19(3) PD 365. Copy of English translation on file with the author.

18. For a review, see Lahav, Judgment in Jerusalem, pp. 181-195 and references there. See also R. Harris, "State Identity, Territorial Integrity, and Party Banning: A Pan-Arab Political Party in Israel," Socio-Legal Review 4 (2008): 19.

19. Like Whitney v. California, 274 US 357, 377 (1927), Yeredor may be viewed as a freedom of association case, rather than as a strictly freedom of expression case. However, the centrality of the case cannot be appreciated without understanding its ramifications for freedom of expression.

20. Justice Sussman joined Chief Justice Agranat in this result, drawing inspiration from the German Basic Law. Justice Chaim Cohn issued a powerful dissent, arguing that only a statute could permit the ban.

21. Yeredor, p. 388, quoting State Papers by Abraham Lincoln (1907), 9. Agranat ended this quote by stating, "The reply given to this question by the glorious President [Lincoln], in theory and in practice, is known to all." Agranat, Lincoln Speech of July 4, 1861, ibid.

22. Basic Law: The Knesset (Amendment 9), http://knesset.gov.il/laws/special/eng/ basic2 _eng.htm.

Amendment of section 7A

1. In the Basic Law: The Knesset, the following section shall be inserted after section 7 "Prevention of participation of candidates' list 7A. A candidates' list 
shall not participate in elections to the Knesset if its objects or actions, expressly or by implication, include one of the following:

(1) negation of the existence of the State of Israel as the state of the Jewish people;

(2) negation of the democratic character of the State;

(3) incitement to racism."

For a discussion, see Barak, Judge in a Democracy, pp. 28-32.

23. Examples of the "dark" disposition of US law to suppress rights are the wave of convictions under the Espionage Act during World War I: O’Brien v. United States, 391 US 367, 382, 88 S.Ct. 1673, 1681 (1968), and more recently Holder v. Humanitarian Law Project, 130 S.Ct. 2705, 2730 (2010). See Geoffrey R. Stone, War and Liberty, An American Dilemma: 1790 to the Present (New York: W. W. Norton, 2007).

24. Defense Emergency Regulation, Article 98 (1945), reprinted in Palestine Gazette no. 1442, p. 1080 (Supp. II, 1945). For discussion of the modifications implemented to ease the censorship, see Pnina Lahav, Press Law in Modern Democracies: A Comparative Study (New York: Longman Publishing Group, 1985), pp. 274-277. See also Z. Segal, Freedom of the Press: Between Myth and Reality (Tel Aviv: Papyrus,1996), Moshe Negbi, Freedom of the Press in Israel, and Zaki Shalom, "Golda Meir's Meeting with the Editors in Chief at the Dusk of the Yom Kippur War," Iyunim BiTkumat Yisrael 20, no. 299 (2010) (in Hebrew).

25. For more about the Agranat Commission, see Lahav, Judgment in Jerusalem, p. 223.

26. New York Times Co. v. Sullivan, 376 US 254, 270, 84 S.Ct. 710, 721 (1964). See also Landmark Communications Inc. v. Virginia, 435 US 829, 844 (1978).

27. It is important to observe that since September 11, 2001, the US press has also displayed the characteristics of timidity and deference to the government. In addition, like the American press, Israel's press today is self-consciously motivated by profit, a factor that mitigates its selfunderstanding as a watchdog of the government.

28. See discussion in Lahav, "Israel's Supreme Court," p. 135.
29. New York Times Co. v. Sullivan.

30. See, for example, Hustler Magazine v. Falwell, 485 US 46, 57, 108 S.Ct. 876, 882 (1988).

31. CA 723/74 Haaretz Newspaper Publishing Ltd. v. Israel Electric Company Ltd. [1977] 31(2) PD 281; FH 9/77 Israel Electricity Co. Ltd. v. Ha'aretz Newspaper Publishing Ltd. [1978] 32(3) PD 337. For a discussion of Haaretz v. Electric Company, see Pnina Lahav, "American Influence on Israel's Jurisprudence of Free Speech," Hastings Constitutional Law Quarterly 9 (1981): 21, 69-99.

32. National Socialist Party of America v. Village of Skokie, 432 US 43, 44, 97 S.Ct. 2205, 2206 (1977); see also Philippa Strum, When the Nazis Came to Skokie: Freedom for Speech We Hate (Lawrence: University Press of Kansas, 1999).

33. Israel Electricity Co. Ltd. v. Ha'aretz Newspaper Publishing Ltd., p. 347. For an elaboration, see Lahav, "American Influence," pp. 99-108.

34. For the Kahane phenomenon, see Ehud Sprinzak, The Ascendance of the Israeli Radical Right (New York: Oxford University Press, 1991), pp. 211-251.

35. Recall that in Yeredor, the Court found that the Knesset Elections Committee had inherent powers to ban a party. Twenty years later, the Knesset amended the law to permit the exclusion of political parties, supra n.22.

36. Rubinstein and Medina, Constitutional Law of the State of Israel, vol. 2, p. 733.

37. Section 144 B Penal Code, amended in 1986 to include this offense: Penal Law, 5737-1977 (Amendment 20), 8 LSI 144B (1986) (Israel).

38. See David Kretzmer, "Freedom of Speech and Racism," Cardozo L. Rev. 8 (1987): 445; Amnon Reichman, "The Passionate Expression of Hate: Constitutional Protections, Emotional Harm and Comparative Law," Fordham International Law Journal 31 (2007): 76; Raphael Cohen-Almagor, "The Scope of Tolerance: Regulating Hate and Racial Speech in Israel," Cardozo Journal of International and Comparative Law 405 (2009): 17.

39. R.A.V. v. City of St. Paul, 505 US 377, 391, 112 S.Ct. 2538, 2547 (1992).

40. Beauharnais v. Illinois, 343 US 250, 266, 72 S.Ct. 725, 736 (1952).

41. See Brandenburg v. Ohio, 395 US 444 (1969) (striking down as unconstitutional an 
Ohio criminal syndicalism statute that punished the plaintiff for a speech he made in which he stated, "Send the Jews back to Israel").

42. Beauharnais was never overruled but has not been followed. See, for example, Village of Skokie, p. 43; Brandenburg v. Ohio, p. 446,

43. Matsuda, et al., Words That Wound (Boulder, CO: Westview Press, 1993).

44. HCJ 742/84 Kahane v. Shlomo Hillel, and 5 others [1985], 39 (4) PD 85; HCJ 24/86, HCJ $669 / 85$ Kahane v. Shlomo Hillel, and 5 others [1986], 40 (4) PD 393; HCJ 400/87 Kahane, MK v. Shlomo Hillel [1987], 41 (2) PD 729; HCJ 399/85 Kahane, MKv. Broadcasting Authority [1987], 41 (3) PD 255. See R. Cohen-Almagor, The Boundaries of Liberty and Tolerance: The Struggle Against Kahanism in Israel (Gainesville: University Press of Florida, 1994).

45. City of Boerne v. Flores, 521 US 507, 516, 117 S.Ct. 2157, 2163 (1997).

46. For a poignant analysis of the effects of the occupation on Israel, see David Kretzmer, The Occupation of Justice, the Supreme Court of Israel and the Occupied Territories (Albany: State University of New York Press, 2002).

47. HCJ 14/86 Laor v. Films and Plays Censorship Board [1987] PD 41(1) 421.

48. In 1991 the Knesset repealed the authority of the board over theatrical productions.

Penal Law, 5737-1977 (Amendment No. 35), 8 LSI 144B (1991) (Israel). See also D. BarakErez, "The Law of Historical Films: In the Aftermath of Jenin Jenin," University of Southern California Interdisciplinary Law Journal 16 (2007): 495.

49. HCJ 680/88 Shnitzer v. Chief Military Censor [1989] 42(4) PD 617.

50. Prior to oral argument, the parties agreed that the question of naming or describing the head of the Mossad would not be subject to litigation. The Court therefore avoided this matter. Shnitzer, p. 623.

51. Ibid., sections 13-17. New York Times Co. v. United States, 403 US 713 (1971) (the Pentagon Papers case).

52. For Basic Law: Human Dignity and Freedom, see www.knesset.gov.il/laws/special/eng/ basic3_eng.htm. Basic Law: Human Dignity and Freedom, S.H. 1391. But see Section $10 \mathrm{Va}$ lidity of Laws: "This Basic Law shall not affect the validity of any law ( $\mathrm{din}$ ) in force prior to the commencement of the Basic Law," http:// knesset.gov.il/laws/special/eng/basic3_eng.htm.

53. Guy Bechor, Constitution for Israel (in Hebrew; Or Yehuda: Maariv, 1996), p. 198.

54 . The question only relates to the judicial power to invalidate statutes passed by the Knesset (a matter of constitutional law). Government regulations were always subject to review by the courts (a matter of administrative law).

55. Marbury v. Madison, 5 US 137, 177 (1803).

56. CA 6821/93 United Mizrahi Bank Ltd. v. Migdal Cooperative Village [1995] PD 49 (4) 221.

57. For retired Chief Justice Barak's defense of judicial review, see Barak, Judge in a Democracy.

58. See M. Kremnitzer and M. Ghanayim, "Incitement, Not Sedition: Sedition in the Criminal Law" (working paper no. 7, Israel Democracy Institute, November 1997), www.idi.org.il /PublicationsCatalog/Documents/PP_7 התסה\%,20df (in Hebrew). See also Michal Buchhandler-Raphael, "Incitement to Violence Under Israeli Law and the Scope of Protection of Political Speech Under Israeli Freedom of Speech Jurisprudence: A Comparative Analysis and an Alternative Perspective, http://works.bepress.com/cgi/viewcontent.cgi ?article $=1000 \&$ context $=$ michal_buchhandler _raphael.

59. A Google search on September 20, 2010, in English yielded 47,100 entries.

60. See Lahav, Judgment in Jerusalem, pp. 121144; L. Bilsky, Transformative Justice, Israeli Identity on Trial (Ann Arbor: University of Michigan Press, 2004), p. 19; Y. Weitz, The Man Who Was Murdered Twice: The Trial and Death of Dr. Israel Kasztner (in Hebrew; Jerusalem: Keter, 1995).

61. HCJ 6126/94 Giora Senesh v. the Chairman of the Broadcasting Agency [1999] Takdin Elyon 99 (2) 806. In keeping with aggressive methods of advertising and the fierce competition for viewers, the broadcasting agency repeatedly showed the short segment where Kasztner made the accusation, in full knowledge that this was the most provocative and counterfactual part of the play.

62. One interesting development in the reasoning of the Court had to do with a subtle change of emphasis. Rather than relying on the Declaration of Independence as a source of democratic values and therefore of free expression, as was 
done in Kol Ha'am, the Court relied on Jewish sources. Thus, the Court emphasized the tradition of the prophets, who spoke truth to power, and contrasted this legacy with Maimonides's emphasis on the right to reputation. Ibid.

63. Ibid., p. 811. It should be noted that in relying on New York Times v. Sullivan, the Court also cited Chief Justice Shamgar's opinion in Haiaretz v. Electric Company, which was overruled in the further hearing. Despite the overruling, it appears that Shamgar's approach did persist in Israel's jurisprudence.

64. Ibid., p. 817: “To courageous, self-reliant men, with confidence in the power of free and fearless reasoning applied through the process of popular government, no danger flowing from speech can be deemed clear and present, unless the incidence of the evil apprehended is so imminent that it may befall before there is opportunity for full discussion. If there be time to expose through discussion the falsehood and fallacies, to avert the evil by the processes of education, the remedy to be applied is more speech, not enforced silence. Only an emergency can justify repression. Such must be the rule if authority is to be reconciled with freedom"; Whitney v. California, 274 US 357 (1927), 377.

65. See Kathleen M. Sullivan, "Foreword: The Justices of Rules and Standards," Harvard Law Review 106 (1992): 22; see also United States $v$. Stevens, p. 1585.

66. But it should be noted that there is an important gate through which an Israeli balancer must walk: the limitation provision of Basic Law: Human Dignity and Freedom. Section 8 provides that "there shall be no violation of rights under this Basic Law except by a law befitting the values of the State of Israel, enacted for a proper purpose, and to an extent no greater than is required." Available at http:// knesset.gov.il/laws/special/eng/basic3_eng.htm.

In Senesh, Barak meticulously applied this provision to the question of whether the Broadcasting Agency may be ordered to delete the controversial statement to prevent a breach of the peace. For Barak's philosophy of balancing, see Barak, Judge in a Democracy, pp. 164-176.

67. See discussion of authoritarian legislation inherited from the British mandatory regime and the lack of respect for free expression in the 1950s, supra.
68. The Public Committee Against Torture in Israel v. Government of Israel [1999], 43(4) PD 817.

69. Ibid., see Lahav, "Israel's Supreme Court," p. 136. Itamar Mann and Omer Shatz, "The Necessity Procedure: Laws of Torture in Israel and Beyond, 1987-2009," Unbound, Harvard Journal of the Legal Left, 2010, www.legalleft.org/wp -content/uploads/2011/02/2-necessity_procedure.pdf. On the cusp of the twenty-first century, Israel's Supreme Court also addressed the legal contours of crimes of sedition (incitement to terrorist activity). In two cases decided on the same day in 2000, CA 8613/96 Jabareen v. State of Israel, 54(5) PD 193 [2000] and CA $1789 / 98$ State of Israel v. Benjamin Kahane 54(5) PD 145 [2000], the Court narrowed the definition of incitement in the Prevention of Terrorism Ordinance (1948) but let stand a broad definition of sedition in the Penal Code. These companion cases reflect the tension within Israeli law between the American, more permissive First Amendment jurisprudence and the more restrictive British and continental approach. See Daphne Barak-Erez and David Scharia, "Freedom of Speech, Support for Terrorism, and the Challenge of Global Constitutional Law," http://ssrn.com/abstract $=1735007$, pp. 12-14. It is interesting that the authors place Israel in the European rather than in the American camp. In my opinion the authors' decision is based on their conception of Israeli freespeech jurisprudence as reflected by legislation. An examination of the analysis in both Jabareen and Kahane reveals the deep influence of US jurisprudence on these opinions.

70. Israel's Supreme Court has fifteen justices, and thus one-third women, as does the current US Supreme Court. However, in the past decade, the Israeli Court had a larger number of women than the US Court. Note that Justice Elena Kagan, the third woman on the US Supreme Court, joined her two sisters only in 2010 .

71. For a collection of cases related to this war, see Judgments of the Israel Supreme Court: Fighting Terrorism Within the Law, published by Israel's court system and the Ministry of Foreign Affairs, undated (English translation).

72. HCJ 316/03 Muhammad Bakri v. Censorship Board [2003] Takdin Elyon 2003 (3) 353. See also Barak-Erez, "Law of Historical Films." 
73. See discussion of the 1980s in this chapter.

74. Bakri v. Censorship Board, p. 355.

75. Because it violates Section 8 of Basic Law: Human Dignity and Freedom.

The Court held that given the result in the case, it was not necessary to address this issue. Implied in this dictum was the opinion that the right to free expression is embedded in the term "human dignity." Basic Law: Human Dignity and Freedom, pp. 353-363, Dorner opinion.

76. Limitation clause, Basic Law: Human Dignity and Freedom.

77. Bakri v. Censorship Board, pp. 353, 361.

78. Harlan also connected freedom of expression to "individual dignity," thereby making it more relevant under Basic Law: Human Dignity and Freedom: "[the protection of expression is rooted] in the belief that no other approach would comport with the premise of individual dignity and choice upon which our political system rests," quoting Cohen v. California, 403 US 15, 26 (1971), Justice Dorner's opinion, p. 360.

79. Justice Dorner and Justice Proccacia.

80. See Adam Liptak, "Ginsburg Shares Views on Influence of Foreign Law on Her Court, and Vice Versa," New York Times, April 12, 2009, p. A14.

81. A subsequent lawsuit in defamation against the Jerusalem and Tel Aviv cinemateques ended with a settlement whereby the cinemateques paid the plaintiffs, army reservists who fought in Jenin, the sum of 40,000 Israeli shekels; "Reservists to Receive Compensation for 'Jenin, Jenin' Screening," Ynet, November 11,2007 . A lawsuit in defamation by five reservists was rejected by the district court on the ground that the plaintiffs were not mentioned in the film. This decision is presently pending on appeal before the Supreme Court. E-mail from Moshe Negbi, on file with the author.

82. Bakri v. Censorship Board, p. 362.

83. Lahav, Judgment in Jerusalem, p. 106.

84. Alan Dershowitz, Shouting Fire (Boston: Little, Brown, 2002), p. 187. Justice Grunis joined both the opinions and the result, and thereby Dershowitz's quote was the penultimate segment of the Jenin Jenin opinion.

85. But Justice Dorner's observation in Jenin Jenin should ring in the minds of the decision makers, especially in the aftermath of the Goldstone Report: "During the war and in the follow- ing days the entrance of reporters to the camp was prohibited. One could only learn about the events in hindsight, from testimonies of persons involved, from the investigations of various groups and from eye-sight. The media blackout contributed to the controversy, which is still raging, about what really happened there" [emphasis added], Bakri v. Censorship Board, para. 2.

86. In 1982, the same Association of Foreign Journalists petitioned for unregulated access when the settlement town of Yamit was evacuated following the peace agreement with Egypt. The Court similarly rejected the petition. But Association of Foreign Journalists v. Government of Israel, H.C.J. 236/82 P.D. 36 (2) 637, did not use the American word "pool," and instead used the Hebrew description of "presence of a certain number of media representatives." Dorit Beinisch (now chief justice) was the solicitor general defending the government in this case.

87. See http://en.wikipedia.org/wiki/Anat _Kamm-Uri_Blau_affair. See discussions in Moshe Negbi, Freedom of the Journalist and Press Freedom (Tel Aviv: Open University, 2011), and Ilana Dayan, "Released on Probation," Hairetz, September 14, 2011, for startling discussions of the constraints experienced by the Israeli press. Both Negbi and Dayan are highly regarded Israeli journalists. In Hebrew.

88. See Mordechai Kremnitzer and Shiri Krebs, "From Illiberal Legislation to Intolerant Democracy," Israel Studies Review 26 (2011): 4. See also other entries in the same volume for further discussion of this phenomenon.

89. The Declaration of the Establishment of the State of Israel: "The State of Israel will . . . be based on freedom, justice and peace as envisaged by the prophets of Israel." Official Gazette: Number 1; Tel Aviv, 5 Iyar 5708, 14.5.1948, p. 1, http://knesset.gov.il/docs/eng /megilat_eng.htm.

90. Numbers 23:9, King James version.

91. See, for example, "Israeli Civil Rights Groups See Themselves as Under Siege," New York Times, September 9, 2010, www.nytimes .com/2010/04/06/world/middleeast/06 israel.html. It is interesting to note, however, the similarity between this development and McCarthyism, and that Israelis do understand this resemblance. 